\title{
DEEP-SEA SHRIMPS (DECAPODA: ARISTEIDAE): NEW TARGETS OF THE DEEP-WATER TRAWLING FISHERY IN BRAZIL
}

Paulo Ricardo Pezzuto, José Angel Alvarez Perez \& Roberto Wahrlich

Universidade do Vale do Itajaí

Centro de Ciências Tecnológicas da Terra e do Mar

(Rua Uruguai, 458, Caixa Postal 360, 88.302-202 Itajaí, SC, Brazil)

E-mail: pezzuto@univali.br

\section{A B S T R A C T}

Following the recent expansion of the Brazilian fishery to slope fishing grounds, a new directed trawl fishery for aristeid shrimps emerged since mid 2002. Aristaeopsis edwardsiana has been the main component of the catches attaining $88.4 \%$ of total shrimp production. Aristaeomorpha foliacea and Aristeus antillensis have composed significantly smaller fractions of the landings $(9.8 \%$ and $1.8 \%$ respectively). Two main grounds were located in the southeastern region $\left(\mathrm{ca} .19^{\circ}-25^{\circ} \mathrm{S}\right)$ and one in the northern border of the Brazilian EEZ $\left(\mathrm{ca} .4^{\circ} 30^{\prime}-5^{\circ} \mathrm{N}\right)$. Catches have been extremely concentrated between the 700 and $750 \mathrm{~m}$ isobaths. Mean catch rates of $A$. edwardsiana oscillated between 6.5 and $9.7 \mathrm{~kg} \cdot \mathrm{h}^{-1}$. The other species have been caught at considerably lower rates $(0.1-0.6$ kg. $\mathrm{h}^{-1}$ and $0.1-1.3 \mathrm{~kg} \cdot \mathrm{h}^{-1}$, respectively). A seasonal pattern in A. edwardsiana catches is suggested, with maximum values obtained between July and December. While largely directed to the shrimps, incidental catches of the royal crab (Chaceon ramosae) attained, on average, $22 \%$ of the total landings.

\section{RESUMO}

Seguindo a recente expansão da pesca brasileira para o talude continental, uma nova pescaria de camarões da família Aristeidae tem se desenvolvido desde meados de 2002. O camarão "carabineiro", Aristaeopsis edwardsiana, é o principal componente das capturas, alcançando 88,4\% da produção total de camarões. Os camarões "moruno", Aristaeomorpha foliacea e "alistado", Aristeus antillensis, compõem frações menores das descargas $(9,8 \%$ e $1,8 \%$ respectivamente). Duas áreas principais de pesca foram descobertas na região Sudeste do Brasil $\left(19^{\circ}-25^{\circ} \mathrm{S}\right)$ e uma no limite setentrional da ZEE do país $\left(4^{\circ}-5^{\circ} \mathrm{N}\right)$. As capturas estiveram concentradas entre as isóbatas de 700 e $750 \mathrm{~m}$. As taxas médias de captura de $A$. edwardsiana flutuaram entre 6,5 e $9,7 \mathrm{~kg} \cdot \mathrm{h}^{-1}$. As outras espécies foram capturadas em taxas consideravelmente menores $\left(0,1-0,6 \mathrm{~kg} \cdot \mathrm{h}^{-1}\right.$ e $0,1-1,3 \mathrm{~kg} \cdot \mathrm{h}^{-1}$, respectivamente). Sugere-se uma sazonalidade nas capturas de A. edwardsiana, com valores máximos entre julho e dezembro. Apesar do direcionamento aos camarões, capturas incidentais do caranguejo-real (Chaceon ramosae) alcançaram uma média de $22 \%$ das descargas totais.

Key words: Deep-sea fisheries; Deep-sea shrimps; Bottom trawling; Aristeidae; Brazil

Palavras chave: Pesca profunda, Camarões-de-profundidade; Arrasto-de-fundo; Aristeidae, Brasil.

\section{INTRODUCTION}

Shrimps of the family Aristeidae comprise one of the most valuable deep-water fishing resources, particularly in the Mediterranean Sea, where at least two species - Aristaeomorpha foliacea (Risso, 1816) and Aristeus antennatus (Risso, 1816) - sustain highly profitable fisheries (Cau et al., 2002; Belcari et al., 2003; Sardà et al., 2003a). In the Strait of Sicily only, landings in the order of $1,000 \mathrm{t}$ of $A$. foliacea have sustained a US\$ 10 million per year fishery (Bianchini et al., 2003). In the Tirrenian Sea the same species first trading price ranges from $€ 20$ to 30 per $\mathrm{kg}$ (Belcari et al., 2003).
Species of this family were known to occur off the Brazilian coast (D'Incao, 1995; 1998) but their fishing potential was only verified in recent years as exploratory deep-water trawling produced the first commercial catches in both the northern and southeastern sectors of Brazilian EEZ. These operations were part of a deep-water fishing development program, launched by the Brazilian government in 1998, based on the chartering of foreign vessels by national companies and an intense technological and scientific monitoring of these commercial operations. Since 2000, chartered vessels using pots, bottom longlines, bottom gillnets and otter trawls, started to operate in $200-900 \mathrm{~m}$ deep areas off Brazil, and established the first deep-water fishing 
regimes on under-exploited targets such as the monkfish (Lophius gastrophysus), geryonid crabs (Chaceon notialis and C. ramosae), Argentine hake (Merluccius hubbsi), Argentine squid (Illex argentinus) and other demersal resources (Perez et al., 2002a, b; Pezzuto et al., 2002; Perez et al., 2003; Wahrlich et al., 2004; Perez et al., 2005; Perez \& Wahrlich, 2005).

Aristeid shrimps were first caught incidentally by one of the chartered trawlers in late 2000 (Perez et al., 2003). By the end of 2002 two other trawlers identified profitable concentrations along the slope grounds off southeastern Brazil, which stimulated a rapid development of directed operations aiming at the EU market demands for deep sea shrimps. Since then these shrimps, as recently observed for monkfish and geryonid crabs (Perez et al., 2002a), have motivated the latest deep-water fishery phase in Brazil, whose high value has not only generated economic interest by national and international fishing industry but also an urgent demand for preliminary biological knowledge for upcoming management actions.

This work describes spatial and temporal patterns of the first exploitation episode of deep-water shrimps in Brazilian waters. These elements are the basis for the assessment of sustainable fishing levels of these shrimps as well as the general impact of trawl fishing on the Southwest Atlantic slope ecosystems.

\section{Material and Methods}

The data analyzed derived from two deepwater fishing monitoring systems, developed as part of a scientific cooperation program established between the Brazilian Government and the University of "Vale do Itajaí" (Santa Catarina, Southern Brazil). A Vessel Observer Program (Wahrlich, 2002) and a Fleet Tracking Program (Rodrigues-Ribeiro, 2002) provided fishing position, depth, duration and catch/by-catch composition data of commercial fishing trips conducted by chartered trawlers off Brazilian coast between October 2000 and August 2004. Additionally, observers registered the physical features of all vessels as well as the main gear dimensions and characteristics. In none of the fishing trips the presence of the observers influenced fishing strategies (i.e. latitude and depth choices, duration of the hauls, target species, etc.).

Effort was expressed as trawling hours and catch rates were expressed as $\mathrm{kg}$.hour $\mathrm{r}^{-1}$. Trawling duration and position were measured from the winch stop to the beginning of gear withdraw. Mean catch rates and respective standard errors were calculated by vessel/trip, month and depth strata. Because chartered vessels differed in their temporal fishing patterns and main targets, each of them had their deep-sea shrimp catch analyzed separately. Usually only the vessel "Mar Maria" operated long enough as to allow temporal patterns to be examined.

\section{RESUlts}

Target Species

Chartered trawler operations off Brazilian coast targeted three deep-water shrimp species, all of them included in the family Aristeidae.

Aristaeopsis edwardsiana (Johnson, 1867), the "carabinero" or scarlet shrimp, is the largestbodied of the three species, with a broad geographic distribution including Western Atlantic (from Newfoundland - Canada to Uruguay), Eastern Atlantic (from southern Portugal to South Africa), Indian and Indo-Pacific Oceans (Mozambique, Madagascar, Tanzania, Somalia, Indonesia, Japan and Australia), occurring over 200 to $1,850 \mathrm{~m}$ deep grounds (D'Incao, 1995). The species was caught in localized areas of the northern and southeastern sectors of Brazilian coast, between 243 and $1,158 \mathrm{~m}$ depths (mean $=727 \pm 46 \mathrm{~m}$ ) (Table 1, Fig. 1).

Aristaeomorpha foliacea (Risso, 1827), known as "moruno", "rasposo" or giant red shrimp is also broadly distributed, being recorded in the Western Atlantic from southern Massachussets State (USA) to Rio Grande do Sul State (Brazil). In Eastern Atlantic, the species has been recorded from the Bay of Biscay (France) to South Africa, including the Mediterranean Sea. In the Indian and Indo-Pacific Oceans, the species has been recorded in Mozambique, Madagascar, Tanzania, Maldive Islands, Sri Lanka, Indonesia, Japan, New Zealand and Fiji Islands (D'Incao, 1995). Off Brazil, the species was caught commercially between the 538 and $779 \mathrm{~m}$ isobaths (mean $=719 \pm 20$ $\mathrm{m})$, over localized grounds of the southeastern coast (Table 1, Fig. 1).

Aristeus antillensis A. Milne Edwards \& Bouvier, 1909 , is the third species commonly known as "alistado" shrimp whose occurrence was previously known for the Western Atlantic from Delaware State (USA) to the French Guiana, at depths ranging from 200 and $850 \mathrm{~m}$. Exploratory fishing cruises of the REVIZEE Program (Living Resources of Brazilian EEZ - Brazilian Government) reported the species also in the coast of northern Brazil, along Pará and Maranhão States, between 406 and $626 \mathrm{~m}$ depths (Silva et al., 2002). Chartered trawlers caught this species in $300-1000 \mathrm{~m}$ deep areas (mean $=716 \pm 70$ $\mathrm{m})$, not only off northern Brazil but also in the southeastern sectors, along São Paulo and Rio de Janeiro States, extending significantly its West Atlantic southern distribution limit (Table 1, Fig. 1). 
Table 1. Summary of fishing operations conducted by chartered trawlers that produced deep-water shrimp catches off Brazilian coast. Decimal latitude and longitudes and depths are expressed as ranges where these shrimps were caught. Except in the case of the vessel "Joana", only trips that had deep-sea shrimps among their targets were summarized. In the first trip of the vessel "Mar Maria" latitudes correspond to the Northern Hemisphere. Trawl duration values (hs) are expressed as means \pm SD. n.a.: not available. Other: include all other species retained.

\begin{tabular}{|c|c|c|c|c|c|c|c|c|c|c|c|c|c|c|c|c|}
\hline \multirow[t]{2}{*}{ Vessel } & \multicolumn{3}{|c|}{ Trip } & \multicolumn{2}{|c|}{$\begin{array}{l}\text { Latitude } \\
\left({ }^{\circ} \mathrm{S}\right)\end{array}$} & \multicolumn{2}{|c|}{ Longitude ("W) } & \multicolumn{2}{|c|}{ Depth (m) } & \multicolumn{2}{|c|}{ Hauls } & \multirow{2}{*}{$\begin{array}{c}\begin{array}{c}\text { Aristaeopsis } \\
\text { edwardsiana }\end{array} \\
(\mathrm{kg})\end{array}$} & \multirow{2}{*}{$\begin{array}{c}\begin{array}{c}\text { Aristaeomorpha } \\
\text { foliacea }\end{array} \\
(\mathrm{kg})\end{array}$} & \multirow{2}{*}{$\begin{array}{c}\begin{array}{c}\text { Aristeus } \\
\text { antillensis }\end{array} \\
(\mathrm{kg})\end{array}$} & \multirow{2}{*}{$\begin{array}{c}\begin{array}{c}\text { Chaceon } \\
\text { ramosae }\end{array} \\
(\mathrm{kg})\end{array}$} & \multirow{2}{*}{$\begin{array}{r}\text { Other } \\
(\mathrm{kg})\end{array}$} \\
\hline & Number & Start & End & Min. & Max. & Min. & Max. & Min. & Max. & Number & Duration & & & & & \\
\hline Joana & 1 & $26 / 10 / 2000$ & $12 / 12 / 2000$ & 32.59 & 32.59 & 50.33 & 50.33 & 300 & 300 & 165 & $4.01(1.46)$ & 0 & 0 & 2 & 0 & 120,875 \\
\hline Joana & 2 & $16 / 12 / 2000$ & $22 / 1 / 2001$ & 23.74 & 24.39 & 44.18 & 42.38 & 348 & 460 & 135 & $3.49(0.90)$ & 0 & 0 & 19 & 0 & 148,773 \\
\hline Nuevo Apenino & 9 & $15 / 6 / 2002$ & 29/7/2002 & 23.77 & 24.60 & 41.78 & 44.05 & 356 & 762 & 176 & $4.03(1.13)$ & 640 & 0 & 0 & 1,620 & 81,756 \\
\hline Costa Grande & 2 & $17 / 5 / 2002$ & $25 / 6 / 2002$ & 23.90 & 23.92 & 42.35 & 42.38 & 729 & 762 & 170 & $4.49(2.04)$ & 0 & 0 & 120 & 270 & 76,312 \\
\hline Costa Grande & 6 & $30 / 10 / 2002$ & $1 / 12 / 2002$ & 23.83 & 23.94 & 41.92 & 42.41 & 724 & 751 & 138 & $3.87(1.65)$ & 3,963 & 0 & 0 & 1,974 & 45,817 \\
\hline Costa Grande & 7 & $8 / 12 / 2002$ & 9/1/2003 & 23.86 & 24.58 & 41.99 & 42.75 & 727 & 754 & 140 & $4.20(0.73)$ & 11,198 & 0 & 0 & 3,424 & 144 \\
\hline Costa Grande & 8 & $15 / 1 / 2003$ & 4/3/2003 & 23.85 & 24.09 & 41.88 & 43.00 & 722 & 750 & 192 & $3.79(0.39)$ & 9,095 & 0 & 143 & 4,669 & 0 \\
\hline Costa Grande & 9 & $12 / 3 / 2003$ & $22 / 5 / 2003$ & 23.85 & 24.04 & 41.22 & 42.90 & 728 & 746 & 297 & $4.03(0.76)$ & 4,337 & 830 & 10 & 4,269 & 34,545 \\
\hline Costa Grande & 10 & $28 / 5 / 2003$ & 29/7/2003 & 23.85 & 24.08 & 41.20 & 42.96 & 711 & 746 & 261 & $4.05(0.34)$ & 10,536 & 801 & 266 & 2,008 & 6,790 \\
\hline Mar Maria & 1 & $23 / 8 / 2002$ & $28 / 10 / 2002$ & 4.31 & 5.15 & 47.45 & 50.43 & 428 & 1,158 & 226 & $2.80(1.96)$ & 498 & 0 & 208 & 0 & 51,428 \\
\hline Mar Maria & 5 & $14 / 6 / 2003$ & $15 / 9 / 2003$ & 23.04 & 27.63 & 41.07 & 47.96 & 243 & 865 & 363 & $4.33(0.86)$ & 16,099 & 109 & 8 & 8,820 & 13,286 \\
\hline Mar Maria & 6 & 7/10/2003 & 16/12/2003 & 5.05 & 24.67 & 34.93 & 44.15 & 627 & 797 & 240 & $3.99(0.87)$ & 9,852 & 1,186 & 29 & 2,390 & 636 \\
\hline Mar Maria & 7 & 20/12/2003 & $12 / 1 / 2004$ & 23.86 & 25.18 & 41.96 & 44.16 & 691 & 775 & 82 & $4.67(0.90)$ & 3,304 & 227 & 0 & 830 & 106 \\
\hline Mar Maria & 8 & $23 / 3 / 2004$ & $24 / 5 / 2004$ & 23.83 & 24.67 & 41.83 & 44.14 & 667 & 777 & 244 & $4.59(0.77)$ & 5,906 & 2,344 & 0 & 7,482 & 1,707 \\
\hline Mar Maria & 9 & $4 / 6 / 2004$ & 9/8/2004 & 23.87 & 24.73 & 41.90 & 44.59 & 682 & 775 & 259 & $4.46(0.71)$ & 7,938 & 1,562 & 0 & 3,734 & 2,818 \\
\hline Mar Maria & 10 & $16 / 8 / 2004$ & $12 / 10 / 2004$ & 23.09 & 24.77 & 41.90 & 44.27 & 695 & 768 & 250 & $3.69(0.75)$ & 8,590 & 1,414 & 92 & 2,690 & 9,655 \\
\hline Mar Maria & 11 & 19/10/2004 & $30 / 11 / 2004$ & 23.85 & 24.41 & 41.84 & 43.67 & 696 & 744 & 161 & n.a. & 7,563 & 1,812 & 73 & 1,430 & 455 \\
\hline Favaios & 1 & $4 / 8 / 2004$ & 24/10/2004 & 23.89 & 24.69 & 42.25 & 44.18 & 538 & 762 & 211 & $4.75(0.51)$ & 7,404 & 692 & 0 & 2.518 & 440 \\
\hline Albamar & 1 & $31 / 8 / 2004$ & $11 / 11 / 2004$ & 19.43 & 24.70 & 38.22 & 44.18 & 658 & 809 & 274 & $4.19(0.75)$ & 7,979 & 1,795 & 510 & 3.444 & 401 \\
\hline Lago Castiñeras & 1 & $1 / 10 / 2004$ & $13 / 11 / 2004$ & 19.33 & 24.63 & 38.00 & 43.96 & 702 & 782 & 156 & $4.01(1.16)$ & 4,227 & 459 & 943 & 2.268 & 0 \\
\hline TOTAL & & & & & & & & & & & & 119,129 & 13,231 & 2,423 & 53,80 & 587,354 \\
\hline
\end{tabular}

Fishing Fleet and Total Catch

Commercial exploitation of deep-sea shrimps in Brazil by chartered vessels was preceded by incidental catches of $A$. antillensis obtained off Rio Grande do Sul State $\left(32^{\circ} \mathrm{S}\right)$ by the Portuguese trawler "Joana" during its first authorized trip in Brazilian waters, in November-December 2000. In a subsequent trip, in January 2001, this vessel reported new catches of the same species further north, along Rio de Janeiro and São Paulo State coasts $\left(23^{\circ} \mathrm{S}\right)$ (Table 1). In both occasions, catches did not exceed a few $\mathrm{kg}$ and were concentrated in areas above the $500 \mathrm{~m}$ isobath.

Important catches were only obtained in mid 2002, when new chartered trawlers started their operations in areas deeper than $700 \mathrm{~m}$. Since then two Spanish vessels, "Mar Maria" and "Costa Grande", conducted systematic operations targeting mostly $A$. edwardsiana, the latter departing from Brazilian waters in July 2003 (Table 1). From mid 2004 onwards, deep-sea shrimp trawling was intensified as the newly-chartered Spanish trawlers "Albamar", "Favaios" and "Lago Castiñeiras" along with the Senegalese "Kayar I" and the Mauritanian "TB1" entered the fishery (Table 2). Presently, two additional trawlers under Brazilian flag, "Noé" and "Capitão Lucas", have completed an eight unit trawling fleet directed towards $A$. edwardsiana and other deep-sea shrimp fishing. Unlike the chartered trawlers, however, these national vessels have not been required by law to be observed or tracked by VMS and very little is known of their operations.

Total production of deep-sea shrimps have increased systematically since 2000 as the number of trawlers in operation augmented and new fishing grounds were identified. Until November 2004 total landings of the three species pooled reached $134.8 \mathrm{t}$, mostly composed of whole shrimp and a minor fraction (less than 10\%) of processed "tails". A. edwardsiana has been the main component of the catches attaining $88.4 \%$ of total shrimp production. $A$. foliacea and $A$. antillensis have composed significantly smaller fractions of total shrimp landings (9.8\% and $1.8 \%$ respectively) (Table 3 ).

All three species combined made up $60 \%$ of the total landings, on average, considering only those trips that had deep-sea shrimps as their main target (ranging from $11 \%$ to $83 \%$ ) (Table 1). Secondary components in these landings were chiefly the royal crab (Chaceon ramosae), reaching, on average, $22 \%$ of the landings (ranging from $10 \%$ to $43 \%$ ), and other shellfish and finfish species such as the Gulf hake (Urophycis cirrata), the Argentine hake (Merluccius hubbsi), the Argentine squid (Illex argentinus) and other species that together made up $18 \%$ of the landings (ranging from 0 to $78 \%$ ) (Table 1). 

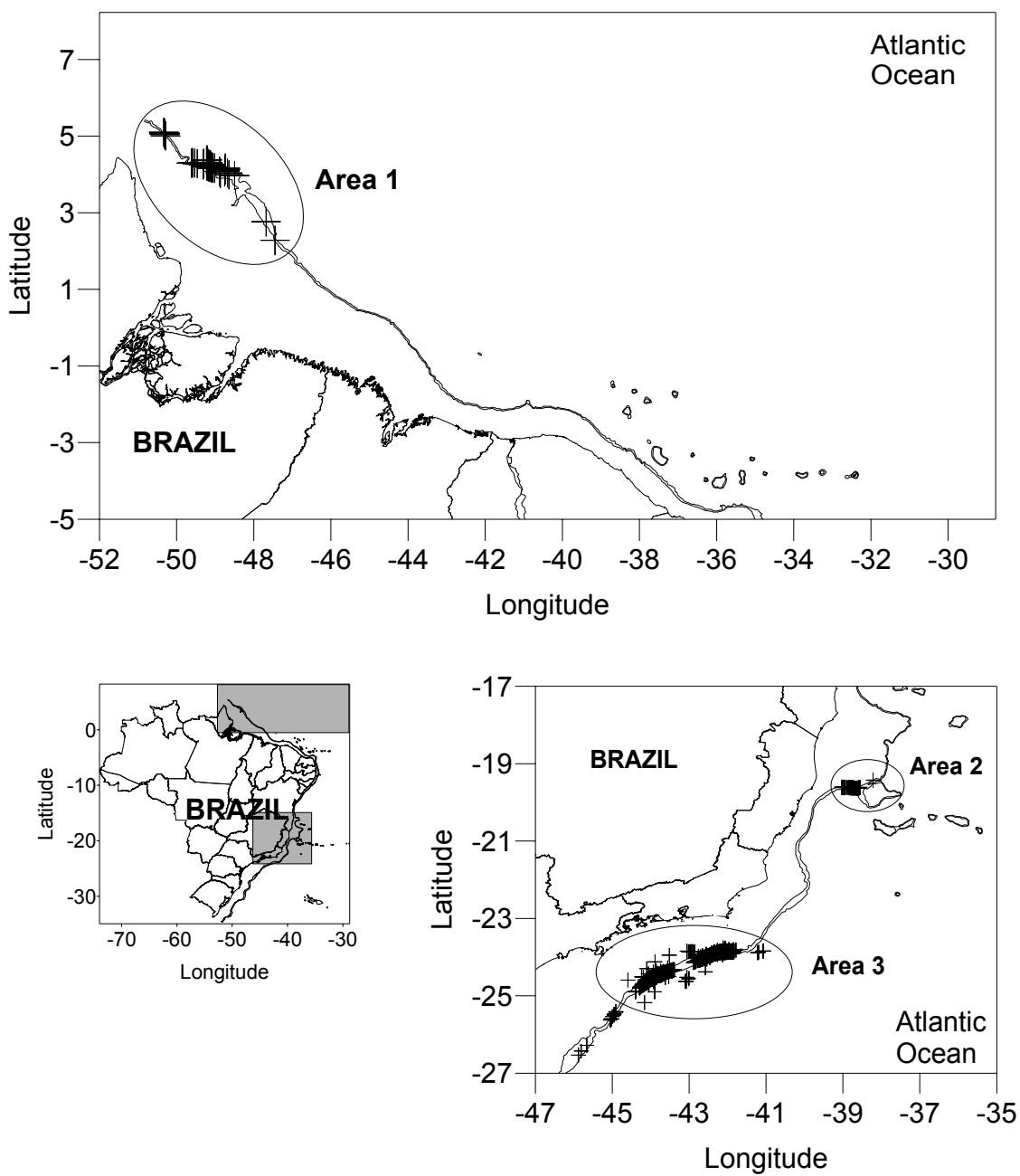

Fig. 1. Distribution of deep-sea shrimp catches reported by chartered trawlers between 2000 and 2004. Main fishing areas are encircled. Isobaths of 500 and $1000 \mathrm{~m}$ are shown in all maps.

\section{Fishing Areas}

Most deep-sea catches have originated from operations off southeastern Brazil, between Rio de Janeiro and São Paulo State coasts $\left(\mathrm{ca} .24^{\circ}\right.$ to $\left.25^{\circ} \mathrm{S}\right)$ (Area 3, Fig. 1). Productive concentrations have also been found by the trawler "Mar Maria" off northern Brazil (Area 1, Fig. 1), where both A. edwardsiana and $A$. antillensis were caught.

Trawlers entering the fishery during the second half of 2004 concentrated their operations directly in area 3 where favorable yields were previously known. However, as this geographically limited area became excessively crowded, some vessels performed exploratory trawls northwards, where a new productive fishing ground (Area 2, Fig. 1) was identified, east of Espirito Santo State (ca. $19^{\circ} 30^{\prime}-20^{\circ} \mathrm{S}$ ). Since then, the exploitation of this area has implied in a significant spreading of fishing effort.

Despite the vast area explored by the chartered fleet since 2000 and the relatively wide bathymetric range where deep-sea shrimps were found to occur, commercial catches of all three species have been extremely concentrated in a restricted depth stratum, delimited by the 700 and $750 \mathrm{~m}$ isobaths. Between $76 \%$ and $88 \%$ of all positive trawls were conducted within this stratum (Fig. 2). 
Table 2. Physical and operational features of the chartered trawlers that caught deep-sea shrimps off Brazilian coast from 2000 to 2004

\begin{tabular}{|c|c|c|c|c|c|c|}
\hline \multirow[t]{2}{*}{ Vessel } & \multirow[t]{2}{*}{ Origin } & \multirow[t]{2}{*}{ Total Length (m) } & \multirow[t]{2}{*}{ GT } & \multirow{2}{*}{$\begin{array}{c}\text { Main engine } \\
(\mathrm{Hp})\end{array}$} & \multicolumn{2}{|c|}{ Operations } \\
\hline & & & & & Start & End \\
\hline Albamar & Spain & 38.0 & 325 & 950 & $25 / 08 / 2004$ & - \\
\hline Costa Grande & Spain & 30.0 & 170 & 800 & $03 / 04 / 2002$ & $31 / 07 / 2003$ \\
\hline Favaios & Portugal & 34.0 & 920 & 900 & $28 / 07 / 2004$ & - \\
\hline \multirow[t]{2}{*}{ Joana } & São Tome and & 60.0 & 890 & 1700 & $25 / 10 / 2000$ & $23 / 01 / 2001$ \\
\hline & Príncipe & & & & & \\
\hline Kayar 1 & Senegal & 29.0 & 252 & 650 & $05 / 11 / 2004$ & - \\
\hline Lago & Spain & 36.4 & 354 & 1000 & $29 / 09 / 2004$ & - \\
\hline \multicolumn{7}{|l|}{ Castineras } \\
\hline Mar Maria & Spain & 38.4 & 271 & 1200 & $23 / 08 / 2002$ & - \\
\hline Nuevo & Spain & 33.0 & 308 & 540 & $10 / 09 / 2001$ & $30 / 07 / 2002$ \\
\hline \multicolumn{7}{|l|}{ Apenino } \\
\hline TB1 & Mauritânia & 37.3 & 276 & 1218 & $12 / 11 / 2004$ & - \\
\hline
\end{tabular}

Table 3. Deep-sea shrimp annual landings (in kg) produced by chartered trawlers between 2000 and 2004 .

\begin{tabular}{rrrrr}
\hline \hline Year & Aristaeopsis edwardsiana & Aristaeomorpha foliacea & Aristeus antillensis & \multicolumn{1}{c}{ Total } \\
\hline 2000 & 0 & 0 & 2 & 2 \\
2001 & 0 & 0 & 19 & 19 \\
2002 & 4,603 & 0 & 120 & 4,723 \\
2003 & 61,615 & 2,926 & 664 & 65,205 \\
2004 & 52,911 & 10,305 & 1,618 & 64,834 \\
Total & 119,129 & 13,231 & 2,423 & 134,783 \\
\hline
\end{tabular}

Catch Rates

Both total catch and catch rates differed significantly among the three deep-sea shrimp species (Table 4). While mean catch rates of $A$. edwardsiana oscillated between 6.5 and $9.7 \mathrm{~kg} \cdot \mathrm{h}^{-1}$, A. foliacea and A. antillensis have been caught at considerably lower rates, on average, with some localized elevated catchrates being obtained specially for the second species.

The catch rate series obtained by the trawler "Mar Maria", which targeted deep-sea shrimps for a longer period and in a broader area than any other chartered vessel in Brazilian waters, indicated that the highest mean catch rates of $A$. edwardsiana (higher than $8.0 \mathrm{~kg} \cdot \mathrm{h}^{-1}$ ) were obtained between the 600 and $800 \mathrm{~m}$ isobaths. These rates declined both towards shallower and deeper grounds, being particularly small in trawls above $600 \mathrm{~m}$ depths where catch rates were lower that $1.0 \mathrm{~kg} . \mathrm{h}^{-1}$ (Fig. 3). The highest catch rates of $A$ foliacea and $A$. were obtained in $600-700 \mathrm{~m}$ and
$700-800 \mathrm{~m}$ depth strata respectively, also with important reductions outside these limits (Fig. 3).

A continuous catch rate series of the trawler "Mar Maria" from June 2003 to October 2004 indicated a likely seasonal pattern in the $A$. edwardsiana catch, with maximum values (over 9.0 $\mathrm{kg} \cdot \mathrm{h}^{-1}$ ) obtained between July and December and rates as low as $5 \mathrm{~kg} \cdot \mathrm{h}^{-1}$ obtained between January and July (Fig. 4).

\section{DisCUSSION}

Marine shrimps were incorporated into the Brazilian fishing industry during late 1960's and are represented by species of the family Penaeidae such as the pink-shrimp Farfantepenaeus subtilis (PérezFarfante, 1967) in the northern coast (Aragão et al., 2004), the sea-bob-shrimp Xiphopenaeus kroyeri (Heller, 1862) mostly in the southeastern coast (Valentini et al., 1991a; D'Incao et al., 2002) and the 

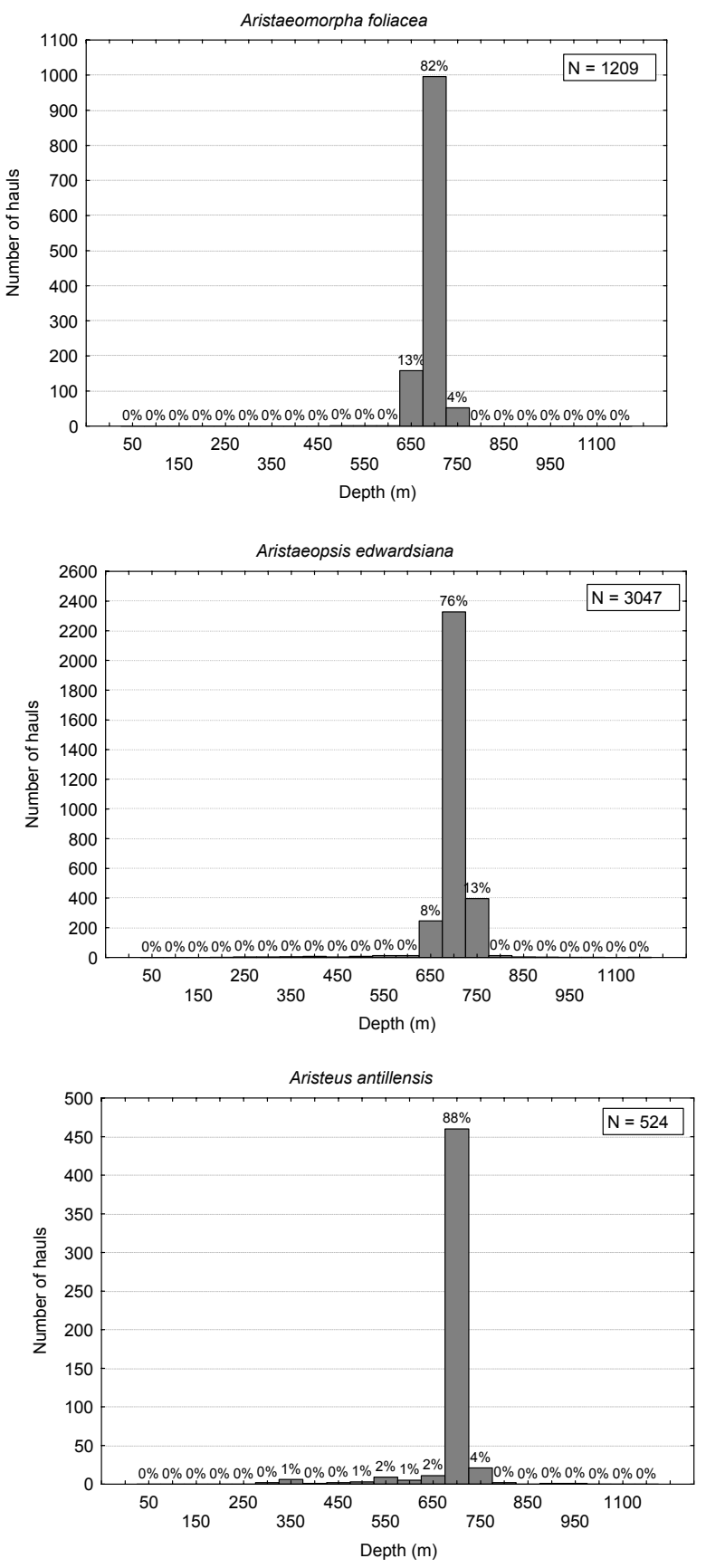

Fig. 2. Bathymetric distribution of positive catches of deep-sea shrimps obtained by the chartered fleet off Brazil between 2000 and 2004 . 
pink-shrimps $F$. paulensis (Pérez-Farfante, 1967) and $F$. brasiliensis (Latreille, 1817) off southeastern and southern Brazil (D'Incao et al., 2002). As the abundance of the two latter species principally declined, trawling became a multispecies activity and other coastal shrimps, Artemesia longinaris Bate 1888 and Pleoticus muelleri (Bate, 1888), were further included among other targets (Perez \& Pezzuto, 1998) Both species have been extensively caught along the coast of Rio Grande do Sul State where they have produced economic returns comparable to those traditionally obtained by the pink-shrimp catches (Perez et al., 2001; D’Incao et al., 2002; Perez et al., 2003).

Table 4. Deep-sea shrimp catch-rate $\left(\mathrm{kg} \cdot \mathrm{h}^{-1}\right)$ patterns obtained by chartered trawlers off Brazilian coast between 2000 and 2004. Mean, Standard Errors (SE), minimum (Min) and maximum (Max) values were extracted from vessels and trips that had these shrimps as their main target. In the case of the vessel "Mar Maria" only those trips and trawls conducted at the southeastern sector of Brazilian coast are included.

\begin{tabular}{|c|c|c|c|c|c|c|c|c|c|c|}
\hline \multirow{2}{*}{ Vessel } & \multicolumn{3}{|c|}{ Aristaeopsis edwardsiana } & \multicolumn{3}{|c|}{ Aristaeomorpha foliacea } & \multicolumn{3}{|c|}{ Aristeus antillensis } & \multirow{2}{*}{$\begin{array}{c}\text { Number of } \\
\text { hauls }\end{array}$} \\
\hline & Mean & SE & Mín-Max & Mean & SE & Mín-Max & Mean & $\mathrm{SE}$ & Mín-Max & \\
\hline Mar Maria & 8.41 & 0.14 & $0-52.80$ & 0.18 & 0.01 & $0-6.27$ & 0.02 & 0.01 & $0-1.52$ & 1451 \\
\hline Costa Grande & 9.66 & 0.26 & $0-46.00$ & 0.20 & 0.03 & $0-11.49$ & 0.10 & 0.01 & $0-2.68$ & 1027 \\
\hline Albamar & 6.81 & 0.29 & $0-27.00$ & 0.21 & 0.03 & $0-5.28$ & 0.44 & 0.04 & $0-4.80$ & 274 \\
\hline Favaios & 7.07 & 0.27 & $0-17.78$ & 0.07 & 0.01 & $0-1.55$ & - & - & - & 211 \\
\hline Lago Castiñeras & 6.52 & 0.35 & $0-26.45$ & 0.59 & 0.10 & $0-11.98$ & 1.32 & 0.18 & $0-13.97$ & 156 \\
\hline
\end{tabular}

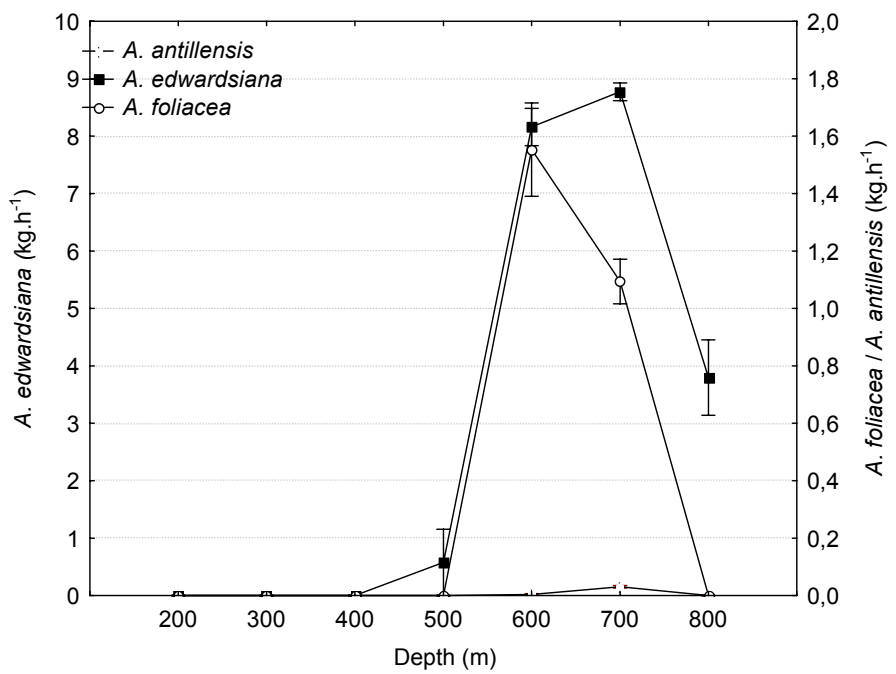

Fig. 3. Mean catch rate $( \pm \mathrm{SE})$ obtained by the trawler "Mar Maria" during fishing trips directed towards deep-sea shrimps off the southeastern coast of Brazil. 

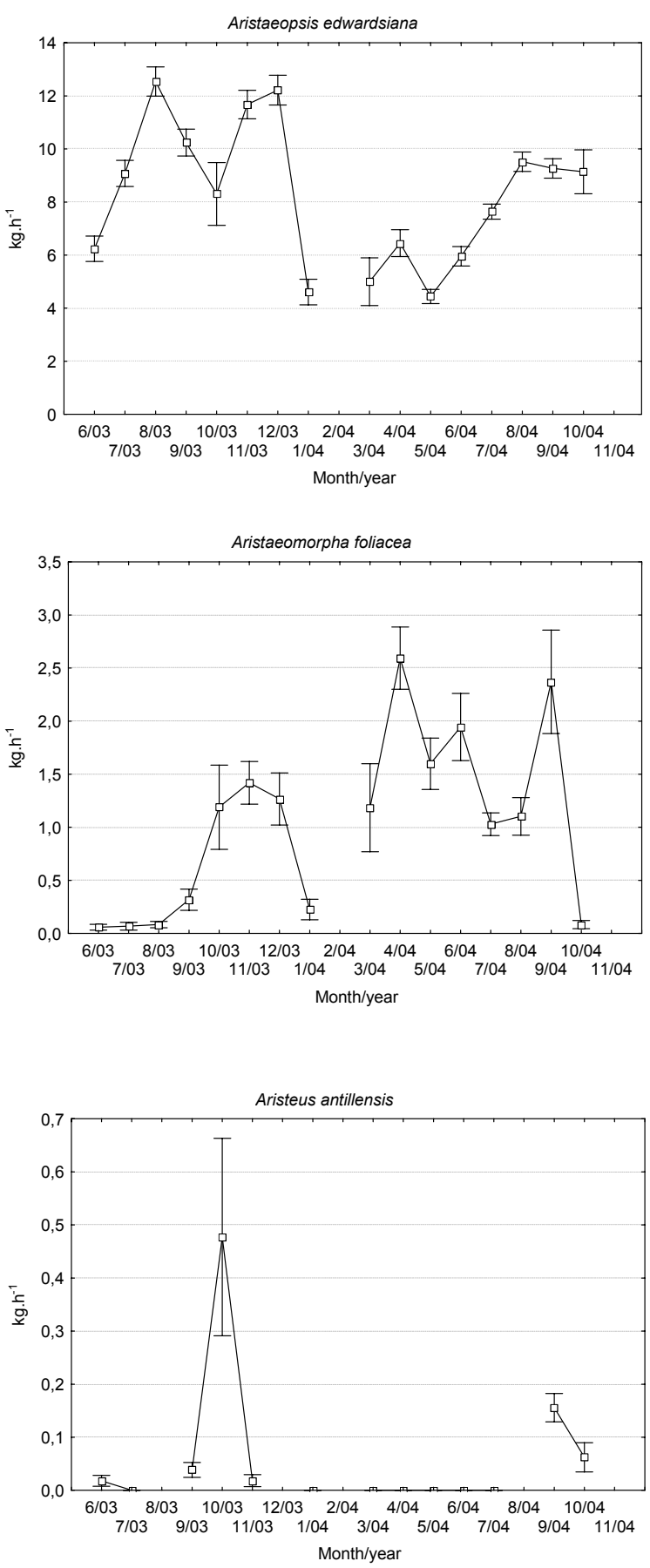

Fig. 4. Deep-sea shrimp mean catch rate $( \pm \mathrm{SE})$ temporal variation obtained by the vessel "Mar Maria" off southeastern Brazil. 
These are coastal species that rarely occur in areas deeper than $70 \mathrm{~m}$, as in the case of the pinkshrimp (Dias Neto, 1991; Valentini et al., 1991a; 1991b). Hence, historically motivated by such targets, national shrimp trawlers have adapted their gear and fishing operations to the extensive flat areas that predominate on the continental shelf in the northern, southeastern and southern sectors of Brazilian EEZ. Limited hull and winch dimension, low powered main engines and the use of the double-rig nets, for instance, feature among these adaptations which, in turn, are hardly compatible to operations in deeper grounds where aristeid shrimps concentrate. In fact, and as observed in other areas of the world (Roberts, 2002), during the last four years, a considerable part of these fleet extended their operations to shelf break areas as valuable concentrations of the monkfish, the Gulf hake, the Argentine squid and other underexploited demersal species became highly attractive, in particular, to compensate for the economic losses produced by the generally collapsed coastal resources (Perez et al., 2002a). Such expansion, however, did not surpass the $350-400 \mathrm{~m}$ isobaths, due to the technological limitations referred above.

A similar scenario has been described in the coast of French Guiana where double-rig shrimp trawlers have targeted deep-sea shrimps during the dry-season, as catch rates of the coastal pink shrimp (F. subtilis) decrease. While profitable, these operations, however, have been often limited by technological/operational restraints (Guéguen, 2000). Such restraints were only overcome by the fishing industry in Brazil through the chartering of foreign trawlers capable of operating on fishing grounds over $500 \mathrm{~m}$ deep (Perez et al., 2003). Hence, unlike what has been observed in northwestern Mediterranean Sea, where deep-sea shrimps have been exploited for over 60 years (Sardà \& Cartes, 1994), the exploitation of these shrimps off the Brazilian coast has only initiated after 2000.

Deep-sea fishing in Brazil has been conducted by a limited number of medium-sized factory vessels (longer than $30 \mathrm{~m}$ and with main engines ranging from 540 to $1200 \mathrm{HP}$ ) that operated 60 to 90 day trips, in a 24-hour regime, performing under four trawls per day, each one over four hours long. These fishing patterns are somewhat contrasting with those reported for traditional deep-sea shrimp fisheries elsewhere, such as the Mediterranean and off Australian coast, particularly as trips in the Brazilian fishery seem to have been longer and vessels slightly larger. Off Barcelona (N W Mediterranean) Aristeus antennatus fishing has been conducted by 17 to $21 \mathrm{~m}$ long trawlers powered by 800-1100 HP main engines. This fleet operates only five days a week, performing typically two 3.5 hour long trawls per day always during daytime (Sardà \& Maynou, 1998; Sardà et al., 2003a). Around Mallorca Island, there are around forty deep-sea shrimp vessels powered by engines ranging from 200 to $450 \mathrm{HP}$ (Carbonell, 1994). In the Sicilian Channel, Aristaeomorpha foliacea is caught by 100 trawlers with up to $1000 \mathrm{HP}$ engines that conduct 2 to 3 week long trips and 3 to 4 hour long trawls (Ragonese et al., 1994). Finally in NW Australia, the same species is caught by shrimp trawlers approximately $25 \mathrm{~m}$ long, employing nets adapted from coastal penaeid shrimp fisheries. These vessels conduct 4 week fishing trips nearly when 4 hour long trawls are normally carried on (Wadley, 1994).

The exploratory scenario of the incipient commercial deep-sea fishing off Brazil, including remote poorly known fishing grounds, may have justified the incidence of robust vessels and long fishing regimes. As fishing areas, effort patterns and market demands become well established, fleet structure and fishing operation changes may be expected in the direction of economic optimization.

Despite fishing particularities, mean catch rates obtained in Brazil, principally of $A$. edwardsiana, lay within ranges reported for Aristeid shrimps either by commercial operations or exploratory surveys worldwide. In the Mediterranean, Aristeus antennatus mean catch rates have oscillated between 3.3 and 4.9 kg.h ${ }^{-1}$ off Murcia (Baños, 1994), 4 and $25 \mathrm{~kg} . \mathrm{h}^{-1}$ around Mallorca Island (Carbonell, 1994) and 6.3 and $10.9 \mathrm{~kg} \cdot \mathrm{h}^{-1}$ off Barcelona (Sardà et al., 1997). Along the Portuguese continental slope, yields from the same species have varied from 0.01 to $8.0 \mathrm{~kg} . \mathrm{h}^{-1}$ (Figueiredo et al., 2001). According to Ragonese et al. (1994), A. foliacea catch rates obtained by experimental trawling in the Sicilian Channel attain $3 \mathrm{~kg} \cdot \mathrm{h}^{-1}$ although historical records include $25 \mathrm{~kg} \cdot \mathrm{h}^{-1}$ in the early 1960 's, $8 \mathrm{~kg} . \mathrm{h}^{-1}$ in 1972 and $5 \mathrm{~kg} \cdot \mathrm{h}^{-1}$ in 1984 . Catch rates from 0.01 to $9.6 \mathrm{~kg} \cdot \mathrm{h}^{-1}$ and between 25 to $50 \mathrm{~kg} \cdot \mathrm{h}^{-1}$ have been obtained for the latter species during research surveys conducted off Portugal and by commercial trawlers operating in the NW Australia, respectively (Wadley, 1994; Figueiredo et al., 2001) Exploratory and commercial operations reported by Guéguen (1998; 2000; 2001) along the French Guiana slope (Central Atlantic), next to the northern Brazilian coast, revealed mean catch rates ranging from 3.7 to 10 $\mathrm{kg} . \mathrm{h}^{-1}$ of $A$. edwardsiana and $0.4 \mathrm{~kg} \cdot \mathrm{h}^{-1}$ of $A$. antillensis. Yields obtained for $A$. edwardsiana along Portugal are, however, much lower than in Guiana and Brazil, as maximum reported values attained less than $2.0 \mathrm{~kg} . \mathrm{h}^{-1}$ (Figueiredo et al., 2001).

Beside the catch rate similarities, deep-sea shrimp fisheries described in both Brazil and French Guiana (Guéguen, 2000), have been characterized (a) 
by a strong predominance of $A$. edwardsiana, highly concentrated in the vicinity of the $700 \mathrm{~m}$ isobath, and (b) by the absence of A. foliacea as verified in a total of 84 trawls conducted during four scientific surveys off French Guiana, and also in the operations of the chartered trawler "Mar Maria", who caught exclusively $A$. edwardsiana and $A$. antillensis in northern Brazil.

The remarkably strict bathymetric distribution pattern of A. edwardsiana, evidenced in both central and SW Atlantic, also approximated that reported for $A$. antennatus in the Mediterranean. According to Sardà et al. (2003a), this species "presents a well-defined distribution pattern (...). The number of individuals (...) rose sharply from 750 to $800 \mathrm{~m}$, that is, over a depth interval of around $500 \mathrm{~m}$ (sic), spatially equivalent to about one mile, given the bottom configuration at the study location. From 900 $\mathrm{m}$ shrimp abundance fell off gradually over a distance of about five or six miles down to a depth of around $1200 \mathrm{~m}$, though shrimp distribution continues over a distance of several dozen miles out to the bathyal zone". Given such common feature, off Brazil, after an early exploratory period, the chartered fleet targeting deep-water shrimps concentrated fishing effort within an extremely narrow area delimited by the 700 and $750 \mathrm{~m}$ isobaths (Fig. 2), where maximum yields were obtained, specially for A. edwardsiana (Fig. 3)

Spatial and temporal segregation of sizes and sexes have been commonly reported for deep-sea shrimps, in association with complex mobility patterns (Sardà \& Cartes, 1993; Sardà et al., 1997; Figueiredo et al., 2001; Sardà et al., 2003a; 2003b; Tudela et al., 2003; Politou et al., 2004; Sardà et al., 2004a) and highly seasonal reproductive events (Figueiredo et al., 2001; Sardà et al., 2003a). In some cases, this seasonality defines the formation of vulnerable reproductive concentrations which generate catch temporal fluctuations. According to Sardà et al. (2003a) reproductive aggregations of A. antennatus are well defined in NW Mediterranean, from late winter to early summer, at $400-900 \mathrm{~m}$ depths. Fishing effort concentrates during these periods as (a) shrimps aggregate on accessible areas, (b) large females predominate contributing for a biomass peak and (c) marketability is highest. Population biology patterns of deep-sea shrimps exploited off Brazil are still unknown. Nevertheless, temporal oscillations exhibited by $A$. edwardsiana catch rate series in SE Brazil suggest, again in accordance with patterns described for $A$. antennatus, a seasonal catch regime with a winter - spring peak. The association of such regime with a likely annual reproductive cycle (as detected for A. edwardsiana by Guéguen, 1998 in French Guyana) is hypothetical at the moment but is to be evaluated soon as commercial catches have been continuously sampled for biological parameters.
In the Mediterranean, $A$, foliacea and $A$. antennatus fisheries have been sustained by large individuals which are priced 3-4 times the smaller ones. These fisheries have also been regarded as monospecific since no other economically important species is caught incidentally (Ragonese et al., 2001). In NW Australia, on the other hand, A. foliacea is caught along with the astacid Metanephrops sp. and other five shrimp species, characterizing a multispecies activity (Wadley, 1994). In Brazil, trawlers targeting deep-sea shrimps have retained moderate catches of other valuable resources, in particular the royal-crab Chaceon ramosae, which has also been subject of a monospecific pot fishery, conducted in areas deeper than $500 \mathrm{~m}$ between $17^{\circ}$ and $30^{\circ} \mathrm{S}$. A recently implemented management plan for this fishery authorizes the operation of three vessels and an annual $600 \mathrm{t}$ TAC. In addition, unauthorized vessels are allowed to land royal-crab catches not exceeding $5 \%$ of the trip total landing, a fraction defined prior to the development of the deep-sea trawl fishing and mostly concerned with abundant incidental catches produced by another developing deep-water fishery directed towards the monkfish Lophius gastrophysus using gillnets (Perez \& Wahrlich, 2005).

In 2004, the incidental catches of crabs retained by deep-sea shrimp-trawlers attained $20.2 \mathrm{t}$, $3.3 \%$ of the annual TAC. While this value is not significant, it is important to consider that for at least half of the referred period only one trawler operated off SE Brazil. An increasing impact on Chaceon spp. is expected in future years as a result of the continuous fishing effort exerted by a larger fleet. In the short run, it will be possible to predict that this impact may affect all three fisheries (deep-sea shrimps, royal crab and monkfish) management plans and challenge their need to address their economic equilibrium and biological sustainability of $C$. ramosae stock

The trawling fishery for deep-sea shrimps in Brazil has not been subject to management actions hitherto as it has been regarded by the Brazilian fishing authorities as exploratory. Nevertheless, as the fleet rapidly increased and concentrated in localized profitable areas of the southeastern coast, a major concern has arisen regarding uncertain impacts on undimensioned but highly susceptible to fishing mortality deep-water stocks and respective habitats (Hastie, 1995; Roberts, 2002; Large et al., 2003; Sardà et al., 2004b; Politou et al., 2004). In that sense, precautionary recommendations have been addressed to fishing authorities priorizing (a) an immediate interruption of the entry of new vessels in the fishery and (b) a rotating harvest strategy, in order to obligate effort to be spread along the Brazilian EEZ. As operations continue to be intensively monitored by observers and VMS, enough fishing, biological and ecological parameters are expected to be made 
available in the near future so as to promote upcoming management actions towards the sustainability of another emerging deep-water fishery in Brazil.

\section{ACKNOWLEDGEMENTS}

The authors are indebted to all members of the Chartered Fleet Observers Program and the Chartered Fleet Tracking Program for their hard work and the quality of collected data. We also thank vessel owners, captains and crew members of all monitored vessels for the support and good will during the long fishing trips. The Department of Fishery and Aquaculture, Ministry of Agriculture and Special Secretary of Aquaculture and Fisheries (Brazilian Government) provided funds for this study through a series of scientific cooperation programs with "Universidade do Vale do Itajaí" (MA/SARC/03/2000; MAPA/SARC/DPA/03/2001; MAPA/SARC/DENACOOP/176/2002; SEAP/PR/ 001/2003; SEAP/PR/078/2004; SEAP/PR/064/2005).

\section{REFERENCES}

Aragão, J. A. N.; Cintra, I. H. A. \& Silva, K. C. A. 2004. Revisão dos dados de esforço de pesca e captura das pescarias industriais de camarão-rosa, Farfantepenaeus subtilis (Pérez Farfante, 1967) (Crustacea, Decapoda, Penaeidae) na região norte do Brasil. Bolm. Téc. Cient.CEPNOR, 4(1):1-44.

Baños, P. M. 1994. Fishery and population dynamics of Aristeus antennatus in the region of Murcia (SE Spain). In: Bianchini, M. L. \& Ragonese, S. eds. Proceedings of the International Workshop "Life cycles and fisheries of the deep-water red shrimps Aristaeomorpha foliacea and Aristeus antennatus". N.T.R.I.T.P.P. Spec. Publ., 3:1112.

Belcari, P.; Viva, C.; Mori, M. \& De Ranieri, S. 2003. Fishery and biology of Aristaeomorpha foliacea (Risso, 1827) (Crustacea: Decapoda) in the Northern Tyrrhenian Sea (Western Mediterranean). J. Northw. Atl. Fish Sci., 31:195-204.

Bianchini, M. L.; Ragonese, S. \& Levi, D. 2003. Management hypotheses to improve yield-per-recruit and economic returns in the red shrimp (Aristaeomorpha foliacea) fishery of Southern Sicily (Mediterranean Sea). J. Northw. Atl. Fish Sci., 31:233-243.

Carbonell, A. 1994. The status of fishery for Aristeus antennatus in Majorca Island waters. In: Bianchini, M.L. \& Ragonese, S. eds. Proceedings of the International Workshop "Life cycles and fisheries of the deep-water red shrimps Aristaeomorpha foliacea and Aristeus antennatus". N.T.R.I.T.P.P. Spec. Publ., 3:15-16.

Cau, A.; Carbonell, A.; Follesa, M. C.; Mannini, A.; Norrito, G.; Orsi-Relini, L; Politou, C.Y.; Ragonese, S. \& Rinelli, P. 2002. MEDITS-based information on the deep-water red shrimps Aristaeomorpha foliacea and Aristeus antennatus (Crustacea: Decapoda: Aristeidae). Sci. Mar., 66(Suppl. 2):103-124

Dias Neto, J. 1991. Pesca de camarões na costa norte do Brasil. Atlântica, 13(1):21-28.
D'Incao, F. 1998. The Brazilian species of the family Aristeidae Wood-Mason (Crustacea: Decapoda). J. Nat. Hist., 32:1509-1518.

D'Incao, F.; Valentini, H. \& Rodrigues, L. F. 2002. Avaliação da pesca de camarões nas regiões sudeste e sul do Brasil. 1965-1999. Attântica, 24(2):103-116.

Figueiredo, M. J.; Figueiredo, I. \& Machado, P. B. 2001. Deep-water penaeid shrimps (Crustacea: Decapoda) from off the Portuguese continental slope: an alternative future resource? Fish. Res., 51:321-326.

Guéguen, F. 1998. Biologie de la crevette profonde Plesiopenaeus edwardsianus en Guyane Française. C. R. Acad. Sci. Paris, 321:757-770.

Guéguen, F. 2000. Distribution et abondance des crustacés décapodes du talus continental (200-900 m) de Guyane Française. Crustaceana, 73(6):685-703.

Guéguen, F. 2001. Notes sur la biologie de la crevette de profondeur Aristeus antillensis en Guyane Française. C. R. Acad. Sci. Paris, 324:689-700.

Hastie, L. E. 1995. Deep-water geryonid crabs: a continental slope resource. Oceanogr. mar. Biol. a. Rev., 33:561584.

Large, P. A.; Hammer, C.; Bergstad, O. A.; Gordon, J. D. M. \& Lorance, P. 2003. Deep-water fisheries of the Northeast Atlantic: II Assessment and Management Approaches. J. North. Atl. Fish. Sci., 31:151-163.

Perez, J. A. A. \& Pezzuto, P. R. 1998. Valuable shellfish species in the by-catch of shrimp fishery in southern Brazil: spatial and temporal patterns. J. Shellfish Res., 17(1):303-309.

Perez, J. A. A. \& Wahrlich, R. 2005. A bycatch assessment of the gillnet monkfish Lophius gastrophysus fishery off southern Brazil. Fish. Res. 72:81-95.

Perez, J. A. A.; Pezzuto, P. R. \& Andrade, H. A. 2005. Biomass assessment of the monkfish Lophius gastrophysus stock exploited by a new deep-water fishery in southern Brazil. Fish. Res. 72:149-162.

Perez, J. A. A.; Pezzuto, P. R.; Lucato, S. H. B. \& Vale, W.G. 2003. Frota de arrasto de Santa Catarina. In: Cergole, M. C. \& Rossi-Wongtschowski, C. L. D. B. coord. Dinâmica das Frotas Pesqueiras - Análise das principais pescarias comerciais do Sudeste-Sul do Brasil. Avaliação do Potencial Sustentável de Recursos Vivos na Zona Econômica Exclusiva - REVIZEE - Área de Dinâmica de Populações e Avaliação de Estoques. FEMAR, MMA, REVIZEE. p. 117-184.

Perez, J. A. A.; Wahrlich, R.; Pezzuto, P. R. \& Lopes, F. R. A. 2002a. Estrutura e dinâmica da pescaria do peixe-sapo Lophius gastrophysus no Sudeste e Sul do Brasil. Bol. Inst. Pesca, 28 (2):205-23.

Perez, J. A. A.; Pezzuto, P. R.; Rodrigues, L. F.; Valentini, H. \& Vooren, C. M. 2001. Relatório da reunião técnica de ordenamento da pesca de arrasto nas regiões Sudeste e Sul do Brasil. Not. Téc. FACIMAR, 5:3-34.

Perez, J. A. A.; Wahrlich, R.; Pezzuto, P. R.; Schwingel, P. R.; Lopes, F. R. A. \& Rodrigues-Ribeiro, M. 2002b. Deep-sea Fishery off Southern Brazil: Recent Trends of the Brazilian Fishing Industry. J. North. Atl. Fish. Sci. 31:1-18.

Pezzuto, P. R.; Perez, J. A. A.; Wahrlich, R.; Vale, W. G. \& Lopes, F. R. A. 2002. Análise da pescaria dos caranguejos-de-profundidade no sul do Brasil - Anos 2001-2002. Relatório Final. Ações prioritárias ao desenvolvimento da pesca e aqüicultura no sul do Brasil, 
Convênio Ministério da Agricultura, Pecuária e Abastecimento (MAPA), Universidade do Vale do Itajaí, MAPA/SARC/DPA/03/2001 e MAPA/SARC/ DENACOOP/176/2002

Politou, C. Y.; Kapiris, K.; Maiorano, P.; Capezzuto, F. \& Dokos, J. 2004. Deep-sea Mediterranean biology: the case of Aristaeomorpha foliacea (Risso, 1827) (Crustacea: Decapoda: Aristeidae). Sci. Mar., 68(Suppl. 3):129-139.

Ragonese, S.; Zagra, M.; Di Stefano, L. \& Bianchini, M.L. 2001. Effect of codend mesh size on the performance of the deep-water bottom trawl used in the red shrimp fishery in the Strait of Sicily (Mediterranean Sea). Hydrobiologia, 449:279-291.

Ragonese, S.; Bianchini, M. L. Di Stefano, L.; Campagnuolo, S. \& Bertolino, F. 1994. Aristaeomorpha foliacea in the Sicilian Channel. In: Bianchini, M.L. \& Ragonese, S., eds. Proceedings of the International Workshop "Life cycles and fisheries of the deep-water red shrimps Aristaeomorpha foliacea and Aristeus antennatus". N.T.R.I.T.P.P. Spec. Publ. 3:45-46.

Roberts, C. M. 2002. Deep impact: the rising toll of fishing in the deep sea. Trends Ecol. Evol., 17(5):242-245.

Rodrigues-Ribeiro, M. 2002. Manutenção de uma central de controle de rastreamento por satélite de embarcacões arrendadas. Meta 04. Relatório Final. Ações Prioritárias ao Desenvolvimento da Pesca e Aquicultura no Sul do Brasil. Convênio Ministério da Agricultura, Pecuária e Abastecimento (MAPA), Universidade do Vale do Itajaí, MAPA/SARC/DPA/003/2001.

Sardà, F. \& Cartes, J. E. 1993. Distribution, abundance, and selected biological aspects of Aristeus antennatus (Risso, 1816) (Decapoda: Aristeidae) in deep-water habitats in the Western Mediterranean. In: Colloquium Crustacea Decapoda Mediterranea, 4. Thessaloniki, 1989 Proceedings. Scientific Annals of the School of Biology, 1(1):59-73.

Sardà, F. \& Cartes, J. E. 1994. Status of the qualitative aspects in Aristeus antennatus fisheries in North Western Mediterranean. In: Bianchini, M.L. \& Ragonese, S., eds. Proceedings of the International Workshop on "Life cycles and fisheries of the deep-water red shrimps Aristaeomorpha foliacea and Aristeus antennatus". N.T.R.I.T.P.P. Spec. Publ. 3:23-24

Sardà, F. \& Maynou, F. 1998. Assessing perceptions: Do Catalan fishermen catch more shrimp on Fridays? Fish Res., 36:149-157.

Sardà, F.; Company, J. B. \& Castellón, A. 2003a. Intraspecific aggregation structure of a shoal of a Western Mediterranean (Catalan Coast) deep-sea shrimp, Aristeus antennatus (Risso, 1816), during the reproductive period. J. Shellfish Res., 22(2):569-579.

Sardà, F.; Company, J. B. \& Maynou, F. 2003b. Deep-sea shrimp Aristeus antennatus Risso 1816 in the Catalan Sea, a review and perspectives. J. North. Atl. Fish. Sci., 31:127-136.

Sardà, F.: Maynou, F. \& Talló, L. 1997. Seasonal and spatial mobility patterns of rose shrimp Aristeus antennatus in the Western Mediterranean: results of a long-term study. Mar. Ecol. Prog. Ser., 159:133-141.
Sardà, F.; D’Onghia, G.; Politou, C. Y.; Company, J. B.; Maiorano, P. \& Kapiris, K. 2004a. Deep-sea distribution, biological and ecological aspects of Aristeus antennatus (Risso, 1816) in the western and central Mediterranean Sea. Sci. Mar., 68(Suppl. 3):117-127.

Sardà, F.; Calafat, A.; Mar Flexas, M.; Tselepides, A.; Canals, M.; Espino, M. \& Tursi, A. 2004b. An introduction to Mediterranean deep-sea biology. Sci. Mar., 68(Suppl. 3):7-38.

Silva, K. C. A.; Muniz, A. P. M.; Ramos-Porto, M.; Viana, G. F. S. \& Cintra, I. H. A. 2002. Camarões da superfamília Penaeiodea Rafinesque, 1815, capturados durante pescarias experimentais para o Programa REVIZEE/Norte (Crustacea: Decapoda). Bol. Téc. Cient. CEPNOR, 2(1):9-40.

Tudela, S.; Sardà, F.; Maynou, F. \& Demestre, M. 2003. Influence of submarine canyons on the distribution of the deep-water shrimp, Aristeus antennatus (Risso, 1816) in the NW Mediterranean. Crustaceana, 76(2):217-225.

Valentini, H.; D'Incao, F.; Rodrigues, L. F.; Rebelo Neto, J. E. \& Domit, L. G. 1991a. Análise da pesca do camarãosete-barbas (Xiphopenaeus kroyeri) nas regiões sudeste e sul do Brasil. Atlântica, 13(1):171-177.

Valentini, H.; D'Incao, F.; Rodrigues, L. F.; Rebelo Neto J. E. \& Rahn, E. 1991b. Análise da pesca do camarão-rosa (Penaeus brasiliensis e Penaeus paulensis) nas regiões sudeste e sul do Brasil. Atlântica, 13(1):143-158.

Wadley, V. 1994. Biology and fishery of Aristaeomorpha foliacea on the North-West slope of Australia. In: Bianchini, M.L. \& Ragonese, S., eds. Proceedings of the International Workshop "Life cycles and fisheries of the deep-water red shrimps Aristaeomorpha foliacea and Aristeus antennatus". N.T.R.I.T.P.P. Spec. Publ. 3:6364.

Wahrlich, R. 2002. Programa de Observadores de Bordo em Embarcações Arrendadas. Meta 03. Relatório Final. Ações Prioritárias ao Desenvolvimento da Pesca e Aquicultura no Sul do Brasil. Convênio Ministério da Agricultura, Pecuária e Abastecimento (MAPA), Universidade do Vale do Itajaí, MAPA/SARC/ DPA/003/2001.

Wahrlich, R.; Perez, J. A. A. \& Lopes, F. R. A. 2004. Aspectos tecnológicos da pesca do peixe-sapo (Lophius gastrophysus) com rede de emalhar no sudeste e sul do Brasil. Bol. Inst. Pesca, 30(1):87-98

\section{Sources of Unpublished Material}

D’Incao, F. 1995. Taxonomia, padrões distribucionais e ecológicos dos Dendrobranchiata (Crustacea: Decapoda) do Brasil e Atlântico Ocidental. PhD Thesis. Curitiba, Universidade Federal do Paraná. 1v.

(Manuscript received 03 October 2005; revised 16 January 2005; accepted 28 March 2006) 